\title{
Lipochito-Oligosaccharide Nodulation Factors Stimulate Cytoplasmic Polarity with Longitudinal Endoplasmic Reticulum and Vesicles at the Tip in Vetch Root Hairs
}

\author{
Deborah D. Miller, Hetty B. Leferink-ten Klooster, and Anne Mie C. Emons \\ Laboratory of Plant Cell Biology, Department of Plant Sciences, Wageningen University, Arboretumlaan 4, \\ 6703 BD Wageningen, The Netherlands.
}

Accepted 28 July 2000.

Vetch root hair development has four stages: bulge, growing, growth terminating, and full-grown hair. In the assay we used, the nodulation factor induced swellings and outgrowths in growth-terminating hairs. Bulges, swellings, and full-grown hairs have transverse endoplasmic reticulum (ER) and no tip-accumulated vesicles. Growing hairs and outgrowths show vesicle accumulation in the tip and longitudinal subapical ER. Bulge walls and walls of swellings appear mottled.

During Rhizobium-legume interaction, rhizobial nodulation (Nod) factor is sensed by root hairs. In an assay where Nod factors are added to roots growing between slide and cover slip, tips of growth-terminating Vicia sativa spp. nigra L. (vetch) root hairs will swell, and a new tip-growing outgrowth emerges from each swelling (Heidstra et al. 1994). Changes in the $\left[\mathrm{Ca}^{2+}\right]_{\mathrm{C}}$ accompany this deformation process (Cárdenas et al.

Fig. 1. Development of one living root hair, growing at $0.8 \mu \mathrm{m} / \mathrm{min}$. A, Bulge containing cytoplasm at the periphery and a large vacuole in the center emerges from an epidermal cell. B, Young root hair acquiring a polarized cytoplasm. The tip where the vesicle-rich region is located (arrow) appears as a smooth area. $\mathbf{C}$ and $\mathbf{D}$, Growing root hairs that have acquired organelle zonation. The tip contains a cytoplasmic-dense area. $\mathrm{V}=\mathrm{a}$ large vacuole in the basal part of the hair. E, Root hair terminating growth. These hairs have a much smaller cytoplasmic-dense region and vesicle-rich region and more small vacuoles close to the tip. $\mathrm{N}=$ nucleus. F, Full-grown hair that contains a thin layer of cytoplasm located at the periphery and a large vacuole in the center. Bar = $15 \mu \mathrm{m}$. After surface sterilization, Vicia sativa spp. nigra L. (vetch) seeds were imbibed in sterile water and placed on $0.8 \%$ agarose. The plates were set at $4^{\circ} \mathrm{C}$ for 3 days in order to synchronize germination at $20^{\circ} \mathrm{C}$. Seedlings were grown between glass slides containing plant growth medium consisting of $1.36 \mathrm{mM} \mathrm{CaCl}_{2} ; 0.97 \mathrm{mM} \mathrm{MgSO}_{4} ; 1.12 \mathrm{mM} \mathrm{Na}_{2} \mathrm{PO}_{4} ; 1.36 \mathrm{mM} \mathrm{KH}_{2} \mathrm{PO}_{4}$; and $20 \mu \mathrm{M}$ Fe-citrate, pH 6.5 (De Ruijter et al. 1998). Root hairs were observed, and light micrographs of the roots in slides were taken with a Nikon $20 \times$ DIC 0.5 NA or $40 \times$ Plan DIC 0.7 NA objective on a Nikon Optiphot microscope. Images were recorded on a Panasonic wv-E550 3-CCD camera with a Prysm framegrabber and AcQuis 2.0 software (Synoptics Ltd., Cambridge, U.K.)

Corresponding author: A. M. C. Emons; Telephone: +31 317 484329; Fax:+31 317485005 ; E-mail: annemie.emons@pcb.dbw.wau.nl
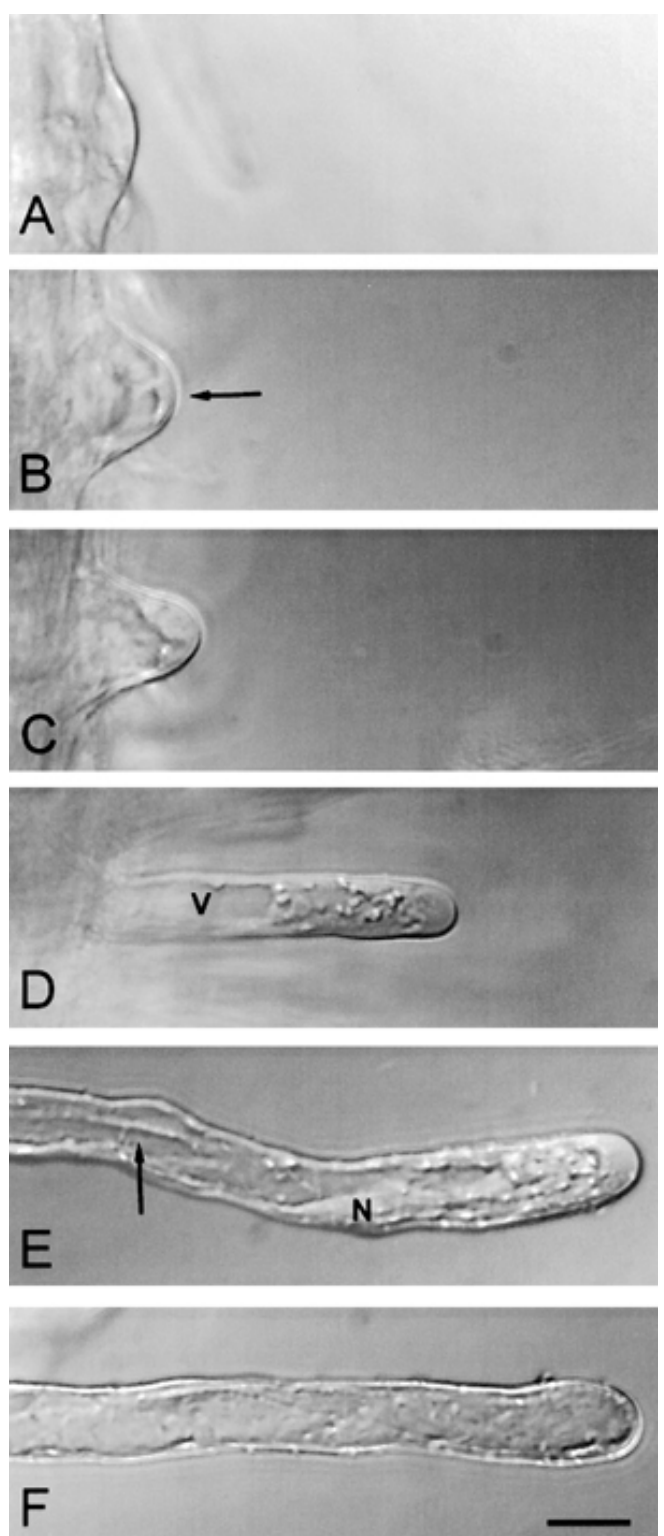
Table 1. Ultrastructural features found with electron microscopy related to the cytoarchitecture seen with differential interference contrast (DIC) microscopy

\begin{tabular}{|c|c|c|c|c|c|c|c|c|c|c|}
\hline & \multicolumn{5}{|c|}{ Electron microscopy } & \multirow{2}{*}{\multicolumn{5}{|c|}{ DIC light microscopy }} \\
\hline & \multirow[b]{3}{*}{$\mathbf{N}$} & \multirow{2}{*}{\multicolumn{3}{|c|}{$\begin{array}{l}\text { Endoplasmic reticulum } \\
\text { orientation to hair axis }\end{array}$}} & \multirow{3}{*}{$\begin{array}{l}\text { Mottled } \\
\text { cell wall }\end{array}$} & & & & & \\
\hline & & & & & & \multirow[b]{2}{*}{$\mathbf{N}$} & \multirow{2}{*}{$\begin{array}{c}\text { Nonrandom } \\
\text { nucleus lo- } \\
\text { cation }(\%)\end{array}$} & \multirow{2}{*}{$\begin{array}{c}\text { Smooth-tip } \\
\text { cytoplasm } \\
(\%)\end{array}$} & \multirow{2}{*}{$\begin{array}{c}\text { Dense subapi- } \\
\text { cal cytoplasm } \\
(\%)\end{array}$} & \multirow{2}{*}{$\begin{array}{l}\text { Reverse foun- } \\
\text { tain stream- } \\
\text { ing }(\%)\end{array}$} \\
\hline & & $\begin{array}{l}\text { accumulated } \\
\text { vesicles in tip }\end{array}$ & Axial & Transverse & & & & & & \\
\hline Epidermal cell & 9 & 0 & 0 & 9 & 0 & $>100$ & 0 & 0 & 0 & 0 \\
\hline Bulge & 11 & 0 & 0 & 11 & 11 & $>100$ & 100 & 0 & 0 & 0 \\
\hline Growing hair & 18 & 18 & 18 & 0 & 0 & $>100$ & 100 & 100 & 100 & 100 \\
\hline \multicolumn{11}{|c|}{ Growth-terminating } \\
\hline hair & 5 & 5 & 0 & 5 & 0 & $>100$ & 50 & 100 & 0 & 100 \\
\hline Full-grown hair & 2 & 0 & 0 & 2 & 0 & $>100$ & 0 & 0 & 0 & 0 \\
\hline Swelling & 7 & 0 & 0 & 7 & 7 & $>100$ & 100 & 0 & 0 & 0 \\
\hline Outgrowth & 4 & 4 & 4 & 0 & 0 & $>100$ & 100 & 100 & 100 & 100 \\
\hline
\end{tabular}
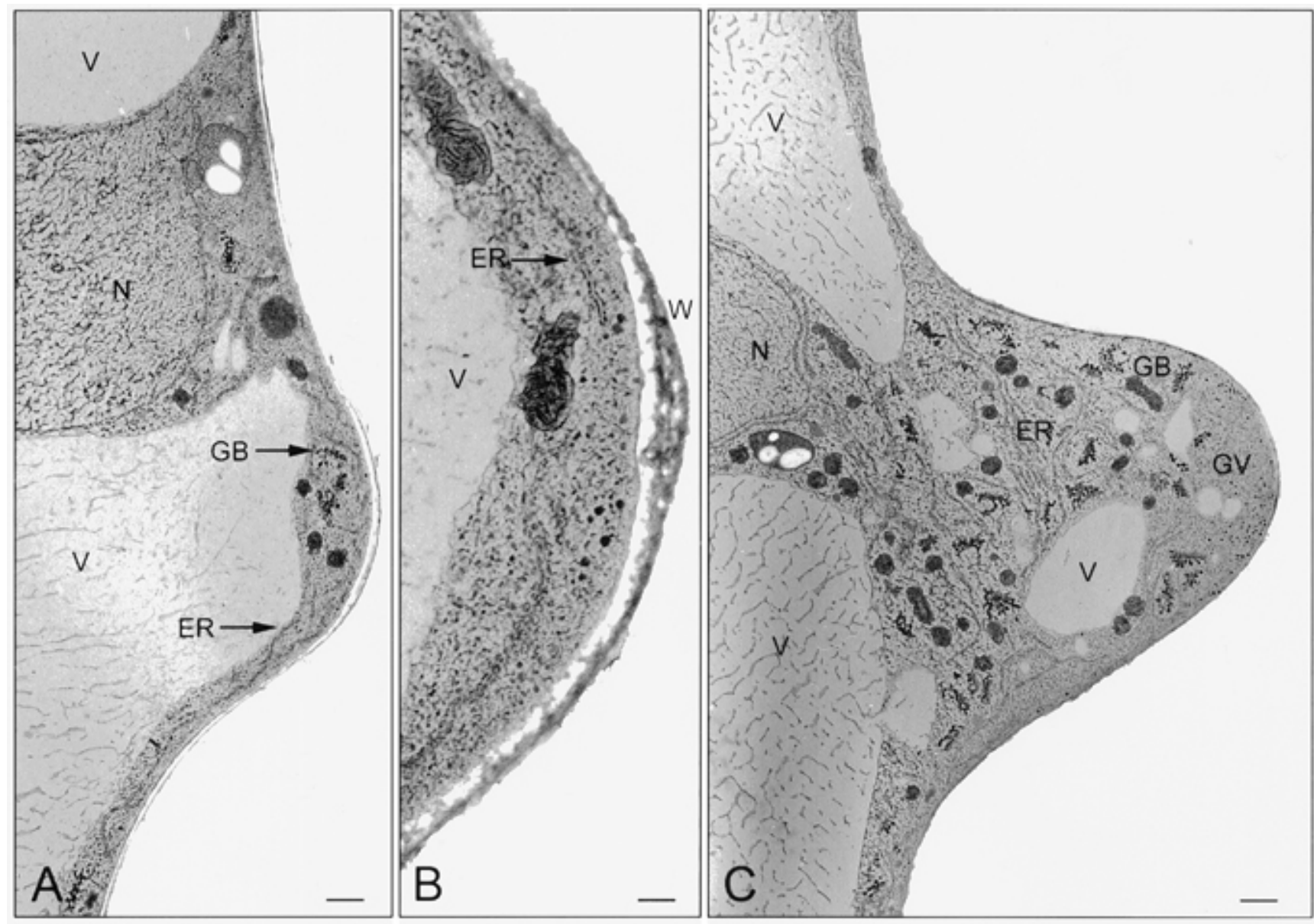

Fig. 2. Ultrastructure of the stages of root hair development. A, Longitudinal section of a bulge emerging from the surface of the epidermal cell. $\mathrm{V}=$ vacuole, $\mathrm{N}=$ nucleus, $\mathrm{GB}=$ Golgi body, $\mathrm{ER}=$ endoplasmic reticulum. $\mathrm{Bar}=1 \mu \mathrm{m}$. B, High magnification of bulge tip. Organelles are seen throughout the cytoplasm. ER is parallel to the long axis of the epidermal cell. No accumulation of vesicles is seen at the bulge tip. The cell wall of the bulge appears mottled (W), but the rest of the epidermal cell wall does not. Bar $=300 \mathrm{~nm}$. C, Transition stage from bulge to root hair. The cytoplasm is polarly organized, with a vesicle-rich region (GV) located at the apex of the root hair. The other organelles, including GB, are located subapically. ER is becoming longitudinally oriented in the subapical region. $\mathrm{N}$ is close to the base of the root hair. Bar $=1 \mu \mathrm{m}$. Roots with hairs were rapidly frozen, freeze-substituted (Miller et al. 1999), and embedded in Spurr's resin. The seedling was removed from the slide and the root tip was excised, placed on a Formvar-coated loop, plunge frozen in liquid propane, and substituted for 36 to $40 \mathrm{~h}$ in $3.7 \%$ paraformaldehyde in pure methanol or pure acetone. The infiltration took place at 4-h intervals with increasing amounts of Spurr's in acetone $\left(1: 5 ; 1: 2 ; 1: 1 ; 2: 1 ; 5: 1\right.$; pure; pure). Samples were polymerized at $60^{\circ} \mathrm{C}$ for $24 \mathrm{~h}$ and sectioned on a Reichert Ultramicrotome. Sections were stained with uranyl acetate and lead citrate in an automatic electron microscopy stainer (LEICA EMstain) and observed in a JEOL EM 1200EXII. 

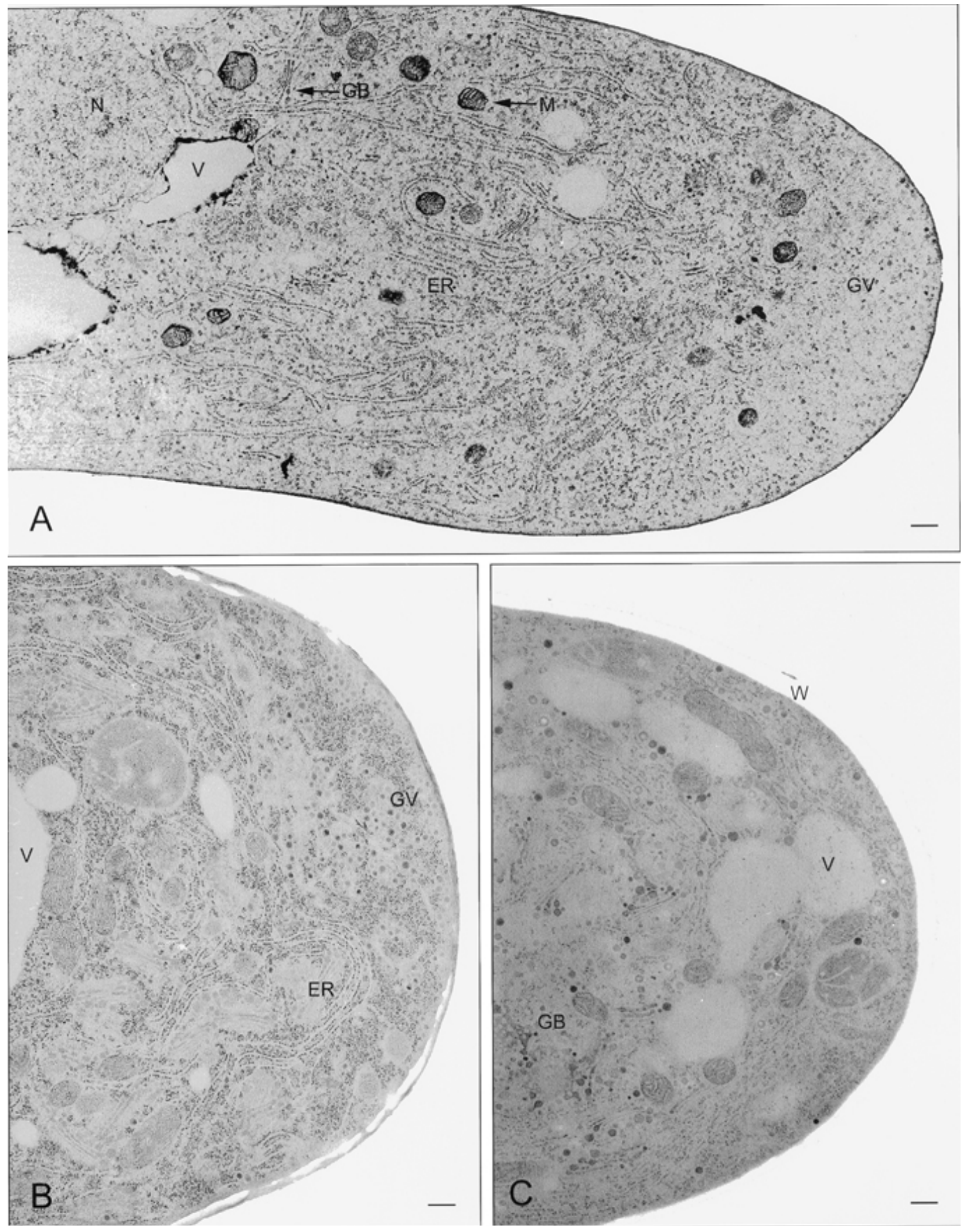

Fig. 3. Ultrastructure of root hair development stages. A, Young, growing root hair. The vesicle-rich region (GV) can be seen at the very apex of the hair. Subapically, all other organelles are observed. The endoplasmic reticulum (ER) is parallel to the long axis of the hair. $\mathrm{M}=$ mitochondrion, $\mathrm{N}=$ nucleus, $\mathrm{V}=$ vacuole. $\mathrm{Bar}=500 \mathrm{~nm}$. B, Root hair in which growth is terminating. Few vesicles are located at the hair tip, and all organelles, including Golgi bodies (GB), are close to the apex. The ER is transverse to the long axis of the hair. Bar $=200 \mathrm{~nm} \mathrm{C}$, Full-grown hair. The cytoplasm is located around the periphery of the cell and no organelle zonation is observed. $\mathrm{W}=$ wall. $\mathrm{Bar}=200 \mathrm{~nm}$. 

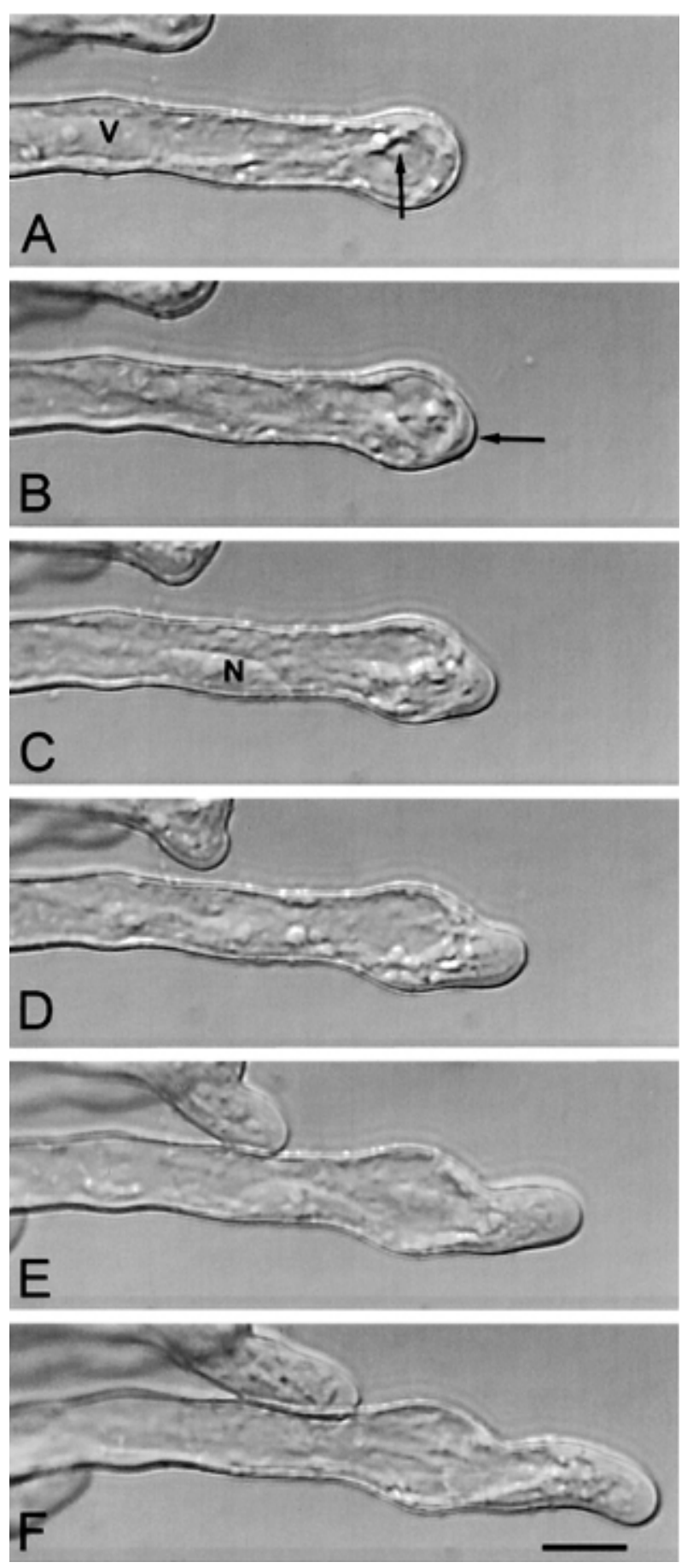

Fig. 4. Nodulation (Nod) factor-induced deformation in a living root hair. A, Swelling of root hair tip 1 h 20 min after Nod factor addition. Swelling lacks cytoplasmic zonation. Arrow points to a cytoplasmic strand that traverses swelling. $\mathrm{V}=$ vacuole. $\mathbf{B}$, Initiation of new root hair tip $1 \mathrm{~h} 41 \mathrm{~min}$ after Nod factor addition. At one side of the swelling a new growth region initiates where the cytoplasm takes on a polarized cytoarchitecture. Arrow indicates a vesicle-rich region building up at one site of the swelling. C-E, New outgrowth from swelling 2 h 29 min after Nod factor addition. $\mathrm{N}=$ nucleus. D, Outgrowth has the same cytoarchitectural features as a growing root hair (E and F). Growth speed of the outgrowth $(0.8 \mu \mathrm{m} / \mathrm{min})$ is comparable to that of a growing root hair. Bar $=15 \mu \mathrm{m}$. Seedlings were treated with $10^{-10} \mathrm{M}$ Rhizobium leguminosarum bv. viciae Nod factors NodRlv V [Ac, C18:4] (Spaink et al. 1992) diluted in plant growth medium.
1999; De Ruijter et al. 1998) as well as occur in the actin cytoskeleton (Cárdenas et al. 1998; Miller et al. 1999) in all developmental stages of the root hairs within 3 min (De Ruijter et al. 1999).

Here we report on the ultrastructural changes that occur during root hair development and Nod factor-induced deformation, focusing on Golgi vesicles and endoplasmic reticulum (ER). Since electron microscopy provides a limited data set, we used differential interference light microscopy of living cells to statistically confirm the relevance of the results (Table 1).

Root hairs are tip-growing extensions of epidermal cells (Derksen and Emons 1990; Miller et al. 1997), and like all plant cells grow by exocytosis, incorporating Golgi vesicle membranes into plasma membranes and their content delivery into an expandable wall. The first stage of root hair development (Figs. 1A to F) is bulge formation (Figs. 1A and 2A, and B) (Dolan et al. 1994), which was reported by Haberlandt in 1887 as "Ausstülpung." The vacuole occupies most of the cell, the nucleus is opposite the bulge, the ER is transverse to the future hair axis (Fig. 2B), and the Golgi bodies are dispersed without any vesicle accumulation (Fig. 2A). The cell wall has a mottled appearance (Fig. 2B), which is never seen before bulge formation. Bibikova et al. (1998) reported wall acidification at the bulge site. The prevention of acidification arrested the process, whereas upon $\mathrm{pH}$ restoration, cell growth resumed. Acid-induced growth has been implied as the basis for root wall extensibility (Pritchard 1994), and acidic proteins (McQueen-Mason et al. 1992) that mediate wall relaxation have been isolated (Wu et al. 1996). It is possible that the expansins are exerting this effect (Link and Cosgrove 1998; Reinhardt et al. 1998).

Dolan et al. (1994) discerned on the basis of growth speed that there is a stage between bulge and tip-growing hair. At this stage, vesicles are delivered to the hair tip for the first time (Fig. 2C), resulting in a 1 - to $2 \mu \mathrm{m}$-long apical vesiclerich region (Figs. 1D and 3A). Vesicles at the growing root hair apex also were reported for freeze-substituted hairs of Equisetum hyemale (Emons 1987), V. hirsuta (Ridge 1988; Ridge 1993), V. villosa (Sherrier and VandenBosch, 1994), and Arabidopsis thaliana (Galway et al. 1997). The subapical region that contains ER, mitochondria, Golgi bodies, and plastids extends from the vesicle-rich region to the nucleus, the tip of which is 20 to $40 \mu \mathrm{m}$ from the hair tip. The formation of the vesicle-rich region accompanies a reorientation of the ER directed to the hair axis (Figs. 2C and 3A). Thus, bulge formation and tip-growth are two distinct processes (Ridge 1995). Wymer et al. (1997) found no $\left[\mathrm{Ca}^{2+}\right]_{c}$ increase preceding bulge formation, but a tip-directed $\left[\mathrm{Ca}^{2+}\right]_{\mathrm{c}}$ gradient was sustained until growth stopped. Furthermore, elevated $\left[\mathrm{Ca}^{2+}\right]_{\mathrm{c}}$ in the tip was absent in the rhd-2 Arabidopsis mutant that forms bulges but no hairs (Wymer et al. 1997). The high $\left[\mathrm{Ca}^{2+}\right]_{\mathrm{c}}$ is probably involved in exocytosis (Carroll et al. 1998).

Cytoarchitecture changes as hair growth ceases (Figs. 1E and $3 \mathrm{~B}$ ). The vesicle-rich region becomes thin, the subapical cytoplasmic-dense region becomes short, and vacuoles move close to the tip. Most of the subapical ER is transverse to the hair axis, but vesicles are present at the tip (Fig. 3B). In a fullgrown hair (Figs. 1F and 3C), the vesicle-rich and cytoplasmic-dense regions are absent, the cytoplasm is a thin layer between the plasma membrane and vacuole, and the nucleus can be anywhere in the cell. 
When the Nod factor is added (Figs. 4A to F), cytoplasmic strands become more numerous in the tip of the growthterminating hairs (Miller et al. 1999; Sieberer and Emons in press) and these tips swell (Fig. 4A). Figure 5A shows a swollen tip. Hardly any vesicles are present at the plasma membrane (Fig. 5B), and the ER is transverse to the hair axis. The wall of swellings stains in a mottled pattern that resembles the wall of bulges, which suggests that the Nod factor alters it (Figs. 5B and C). When the swelling stops, a normal wall is formed next to the mottled wall (Fig. 5C). However,
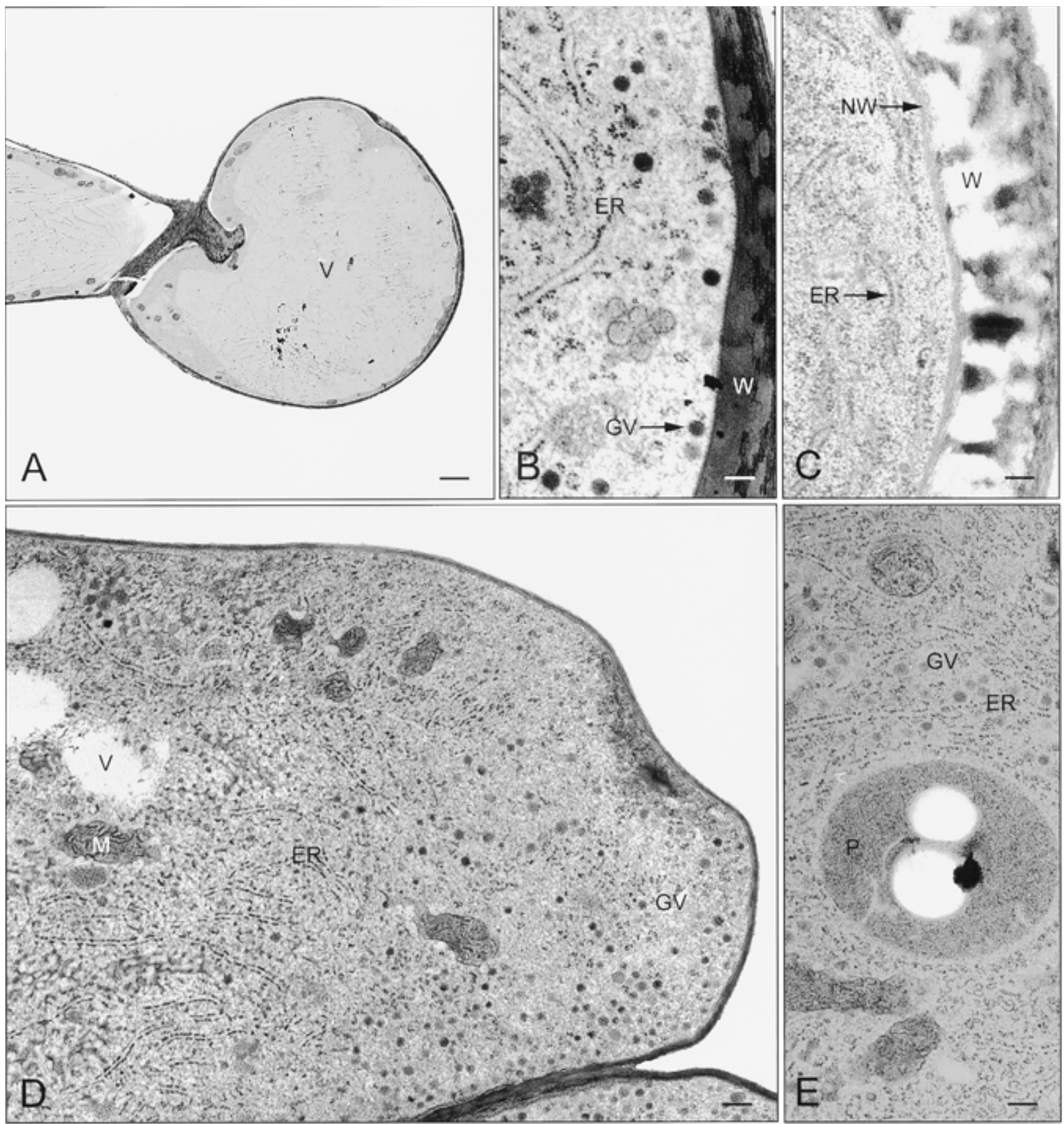

Fig. 5. Ultrastructure of root hairs treated with Nod factor at growth-termination. A, $1 \mathrm{~h} 24$ min after treatment with Nod factor. Hair tip is swollen and organelle zonation is not observed. Most of the swelling is occupied by a large vacuole (V). At the lower side, the section is oblique through the cell wall. $\mathrm{Bar}=2.5 \mu \mathrm{m} \mathrm{B}$, Cross-section at high magnification of the distal portion of the swelling shown in $\mathbf{A}$, illustrating a small number of vesicles at the edge of the swelling next to the plasma membrane (GV). Note the mottled texture of the wall (W). Bar $=200 \mathrm{~nm}$. $\mathbf{C}$, When swelling stops, a new normal cell wall (NW) is deposited along the plasma membrane of the swelling. (1h $10 \mathrm{~min}$ after Nod factor application; lateral side of swelling is shown). $\mathbf{C}$ is a later stage than $\mathbf{D}$; swelling and outgrowth are not synchronous in all hairs of a root. Bar $=200 \mathrm{~nm}$. D, A new outgrowth has emerged from the swelling with the same organelle distribution as a growing root hair. The vesicles are enriched at the apex. The endoplasmic reticulum (ER) is longitudinal to the hair's growth axis. The adjacent root hair in the figure is at the same developmental stage. $\mathrm{M}=$ mitochondrion. Bar $=250 \mathrm{~nm}$. E, In growing root hairs and outgrowths from swellings, Golgi vesicles are often found between the ER strands. $\mathrm{P}=$ plastid. $\mathrm{Bar}=250 \mathrm{~nm}$. 
the method used is not a special cell wall method (Emons 1988). Young, thin walls appear electron transparent (Fig. 3) and may be detached from the plasma membrane (Fig. 2). Figure 5C illustrates the difference between a mottled pattern and a normal wall. The wall composition, however, needs future attention.

Felle et al. (1996) have shown that Nod factors elevate the cytoplasmic $\mathrm{pH}$ in alfalfa root hairs, which may change the wall. Additionally, Nod factor-induced wall modification was reported for root cortical cells (Van Spronsen et al. 1994).

In a swollen hair tip, a spot of elevated $\left[\mathrm{Ca}^{2+}\right]_{\mathrm{c}}$ moves toward the plasma membrane until it anchors somewhere in the swelling. At this site, the new vesicle-rich region forms (Fig. 4B) and tip-growth resumes (Figs. 4C and D) (De Ruijter et al. 1998). Vesicles accumulate in the outgrowth apex, whereas the other organelles are subapical with longitudinal ER (Fig. 5D). Figure 5E shows vesicles in an outgrowth between the ER strands, similar to that in a growing hair.

We see parallels between outgrowths from Nod factorinduced swellings and the formation of tip-growing hairs from bulges. In both, two different events occur. The first is bulge formation and swelling, which is undirected growth accompanied by wall loosening. The second is polar growth. No ultrastructural differences were observed between outgrowth and normally growing hair. Though indirect, the Nod factor stimulates cytoplasmic polarity with vesicles at the tip and longitudinal ER. Without the Nod factor, these hairs would not have acquired a new polarity nor would they have become longer than normal for their species. Extrapolation of these results to Rhizobium-induced root hair curling suggests that curling can be achieved by a local, progressive induction of polarity away from the existing tip (Batenburg et al. 1986; Emons and Mulder 2000).

\section{ACKNOWLEDGMENTS}

The project was funded by a National Science Foundation Postdoctoral Fellowship in Biosciences Related to the Environment, grant DBI 9509441, and a Wageningen University Postdoctoral Fellowship, both granted to D. D. Miller.

\section{LITERATURE CITED}

Batenburg, F. H. D., Jonker, R., and Kijne, J. W. 1986. Rhizobium induces marked root hair curling by redirection of tip growth: A computer simulation. Physiol. Plant 66:476-480.

Bibikova, T. N., Dahse, J. I. T, and Gilroy, S. 1998. Localized changes in apoplastic and cytoplasmic $\mathrm{pH}$ are associated with root hair development in Arabidopsis thaliana. Development (Camb) 125:2925-2934.

Cárdenas, L., Feijo, J. A., Kunkel, J. G. L., Vidali, L., Sánchez, F., Holdaway-Clarke, T., Hepler, P., and Quinto, C. 1999. Rhizobium Nod factors induce increases in intracellular free calcium and extracellular calcium influxes in bean root hairs. Plant J. 19:347-352.

Cárdenas, L., Vidali, L., Pérez, H. J. G. L., Sánchez, F., Hepler, P., and Quinto, C. 1998. Rearrangement of actin microfilaments in plant root hairs responding to Rhizobium etli nodulation signals. Plant Physiol. 116:971-877.

Carroll, A. D., Moyen, C., Van Kesteren, P., Tooke, F., Battey, N. H., and Brownlee, C. 1998. $\mathrm{Ca}^{2+}$, annexins, and GTP modulate exocytosis from maize root cap protoplasts. Plant Cell 10:1267-1276.

Derksen, J., and Emons, A. M. C. 1990. Microtubules in tip growth systems. Pages 147-179 in: Tip Growth in Plant and Fungal Cells. I. B. Heath, ed. Academic Press, New York.

De Ruijter, N. C. A., Bisseling, T., and Emons, A. M. C. 1999. Rhizobium Nod factors induce an increase in sub-apical fine bundles of ac- tin filaments in Vicia sativa root hairs within minutes. Mol. PlantMicrobe Interact. 12:829-832.

De Ruijter, N. C. A., Rook, M. B., Bisseling, T., and Emons, A. M. C. 1998. Lipochito-oligosaccharides reinitiate root hair tip growth in $\mathrm{Vi}$ cia sativa with high calcium and spectrin-like antigen at the tip. Plant J. 13:341-350.

Dolan, L., Duckett, C. M., Grierson, C., Linstead, P., Schneider, K., Lawson, E., Dean, C., Poethig, S., and Roberts, K. 1994. Clonal relationships and cell patterning in the root epidermis of Arabidopsis. Development (Camb) 120:2465-2474.

Emons, A. M. C. 1987. The cytoskeleton and secretory vesicles in root hairs of Equisetum and Limnobium and cytoplasmic streaming in root hairs of Equisetum. Ann. Bot. (London) 60:625-32.

Emons, A. M. C. 1988. Methods for visualizing cell wall texture. Acta Bot. Neerl. 37:31-38

Emons, A. M. C., and Mulder, B. M. 2000. Nodulation factors trigger an increase of fine bundles of subapical actin filaments in Vicia root hairs: Implications for root hair curling around bacteria. Pages 272276 in: Biology of Plant-Microbe Interaction, Vol. 2. P. J. G. M. De Wit, T. Bisseling, and W. J. Stiekema, eds. International Society for Molecular Plant-Microbe Interactions, St. Paul, MN, U.S.A.

Felle, H. H., Kondorosi, É., Kondorosi, Á., and Schultze, M. 1996. Nod signal-induced plasma membrane potential changes in alfalfa root hairs are differentially sensitive to structural modifications of the lipochito-oligosaccharide. Plant J. 7:939-47.

Galway, M. E., Heckman, J. W., Jr., and Schiefelbein, J. W. 1997. Growth and ultrastructure of Arabidopsis root hairs: The rhd3 mutation alters vacuole enlargement and tip growth. Planta 201:209-218.

Haberlandt, G. 1887. Ueber die Lage des Kernes in sich entwickelenden Zellen. Ber. Dtsch. Bot. Ges. 5:205-212.

Heidstra, R., Geurts, R., Franssen, H., Spaink, H. P., Van Kammen, A., and Bisseling, T. 1994. Root hair deformation activity of nodulation factors and their fate on Vicia sativa. Plant Physiol. 105:787-797.

Link, B. M., and Cosgrove, D. J. 1998. Acid-growth response and $\alpha$ expansions in suspension cultures of bright yellow 2 tobacco. Plant Physiol. 118:907-916.

McQueen-Mason, S., Durachko, D. M., and Cosgrove, D. J. 1992. Two endogenous proteins that induce cell wall extension in plants. Plant Cell 4:1425-1433.

Miller, D. D., De Ruijter, N. C. A., Bisseling, T., and Emons, A. M. C. 1999. The role of actin in root hair morphogenesis: Studies with lipochito-oligosaccharide as a growth stimulator and cytochalasin as an actin perturbing drug. Plant J. 17:141-154.

Miller, D. D., De Ruijter, N. C. A., and Emons, A. M. C. 1997. From signal to form: Aspects of the cytoskeleton-plasma membrane-cell wall continuum in root hair tips. J. Exp. Bot. 48:1881-1896.

Pritchard, J. 1994. The control of cell expansion in roots. New Phytol. $127: 3-26$

Reinhardt, D., Wittwer, F., Mandel, T., and Kuhlemeier, C. 1998. Localized upregulation of a new expansion gene predicts the site of leaf formation in the tomato meristem. Plant Cell 10:1427-1437.

Ridge, R. W. 1988. Freeze-substitution improves the ultrastructural preservation of legume root hairs. Bot. Mag. Tokyo 101:427-41.

Ridge, R. W. 1993. A model of legume root hair growth and Rhizobium infection. Symbiosis 14:359-373.

Ridge, R. W. 1995. Recent developments in the cell and molecular biology of root hairs. J. Plant Res. 108:399-405.

Sherrier, D. J., and Van den Bosch, K. A. 1994. Secretion of cell wall polysaccharides in Vicia root hairs. Plant J. 5:185-195.

Sieberer, B., and Emons, A. M. C. 2000. Cytoarchitecture and pattern of cytoplasmic streaming in developing root hairs of Medicago truncatula and during deformation by Nod factors. Protoplasma. In press.

Van Spronsen, P. C., Bakhuizen, R., Van Brussel, A. A. N., and Kijne, J. W. 1994. Cell wall degradation during infection thread formation by the root nodule bacterium Rhizobium leguminosarum is a two step process. Eur. J. Cell Biol. 64:88-94.

Wu, Y. J., Sharp, R. E., Durachko, and D. M., Cosgrove, D. J. 1996. Growth maintenance of the maize primary root at low water potentials involves increases in cell wall extension properties, expansion activity, and wall susceptibility to expansions. Plant Physiol. 111:765-772.

Wymer, C. L., Bibikova, T. N. and Gilroy, S. 1997. Cytoplasmic free calcium distributions during the development of root hairs of Arabidopsis thaliana. Plant J. 12:427-439. 